\title{
Зміни в клітинах і тканинах живих організмів під впливом ударно-хвильової терапії (огляд спеціальної літератури)
}

\author{
О. А. Островський \\ Товариство обмеженої відповідальності «МЕДГАРАНТ»
}

\begin{abstract}
Резюме. На основании анализа зарубежной литературы приведены современные представления о влиянии фокусированных и радиальных волн на клетки и отдельные ткани живых организмов. Раскрыты механизмы, вызывающие боль, улучшение кровообращения, а также лечебный эффект на отдельные ткани, в том числе сухожилия, подошвенную фасцию, костную ткань, замедленную консолидацию переломов, мышечный спазм и др.
\end{abstract}

Ключевые слова: ударная волна, сфокусированная волна, псевдоартроз, подошвенный фасцит, мышечные спазмы.

Summary. Based on the analysis of foreign literature, original experimental studies and clinical trials, the modern ideas of the influence of focused and radial shock waves on cells and individual tissues of living organisms are outlined. The mechanisms causing pain, improving blood circulation as well as healing effect on target tissues, including tendons, plantar fascia, bone tissue, and on hypoporosis and muscle spasms, etc. are disclosed.

Keywords: shock wave, focused wave, pseudarthrosis, plantar fasciitis, muscle spasms.

Існує декілька теоретичних концепцій, що пояснюють виникнення аналгезивного і дедистрофічного ефектів у разі екстракорпоральної ударно-хвильової терапії (ЕУХТ).

На думку одних авторів, проходження квазіакустичних ударних хвиль спричиняє ушкодження нервових закінчень [3]. Інші учені визначають повторне подразнення цих самих нервових закінчень, що має той самий результат, тобто переривається рефлекторна дуга передачі больового імпульсу з патологічної ділянки. Крім того, біологічно активні речовини, що утворюються внаслідок ефекту кавітації у зоні впливу ЕУХT, порушують функцію нервових закінчень та індукують регенераторні процеси у тканинах, у тому числі і кістковій.

За наявності остеофрітів і осифрікацій, кальцієвих відкладень під впливом ударних хвиль іноді відбувається їх дезінтеграція і значно полегшується розсмоктування мікрофрагами.

Фундаментальні дослідження показали, що ударно-хвильова терапія викликає неоднакову відповідь на переходи між тканинами із різним опором - імпендансом [20]. Наприклад, жирова клітковина і м'язова тканина мають порівняно низький імпенданс, а кісткова тканина - високий імпенданс і у п'ять разів більшу звукопровідність [1]. Тому під час проведення експерименту на тваринах логічно було очікувати ефективний вплив ЕУХТ на дистальний епіметафріз стегнової кістки, покритий окістям, у нервових волокнах якої $\epsilon$ Р-субстанція - речовина, котра володіє імунореактивними властивостями і зустрічається в кістковому мозку та синовіальних мембранах $[9,13]$.

До сьогодні не встановлено, чи з'являється біль у сухожилках та у місцях їх прикріплення при ентезопатіях, де відбувається тимчасове зменшення Р-речовини, як це мало місце у дослідженні, проведеному на дистальному відділі кінцівки кроля [7]. Слід взяти до уваги, що Р-субстанція може викликати «нейрогенне» запалення, ознаки якого у пухкій тканині навколо п'яткового сухожилка кроля виявляються вже на наступний день після лікування ударними хвилями високої енергії [11].

Із метою перевірки гіпотези про зміни концентрації Р-субстанції у тканинах живої тварини під впливом ударних хвиль було здійснено лікувальну терапію дистального кінця стегнової кістки кроля ударними хвилями силою 0,9 мДж • мм, після чого визначали концентрацію Р-субстанції у витяжці із окістя стегна [18].

Порівняння 3 контрлатеральною кінцівкою, котра залишалась інтактною, засвідчило значний підйом концентрації вільної Р-субстанції до 24 год. після ударно-хвильової терапії, яка знизилась через 6 тиж. [12].

На четвертому конгресі 3 лікування болю за допомогою ЕУХТ, що відбувся у 2008 р. у 
Берліні, опубліковано працю, в якій ішлося про робочі аспекти молекулярних механізмів ударних хвиль [15]. Автори висловили припущення, що на м'язово-скелетну систему під час розвитку болю можуть впливати кілька фракторів, зокрема рух шокової хвилі.

У роботі «Основи молекулярної біології дії екстракорпоральних хвиль на організм людини» визначено механізми і зміни у окисно-відновному стані клітин під впливом екстракорпоральних хвиль. Проведені дослідження показали, що механізм самозахисту організму активується у відповідь на механічний стрес, викликаний ЕУХТ, а регенерація патологічних процесів, як хронічних так і гострих, може стимулюватися та прискорюватися.

Вважається, що ЕУХТ може викликати тимчасову дегенерацію епідермальних чутливих нервів, але не може впливати ні на ендогенні епіоїди у спинному мозку, ні на діяльність нейронів спинного мозку [11]. Експерименти, проведені на тваринах, свідчать, що ЕУХT може стимулювати маркери, котрі належать до ангіогенезу, і неоваскуляризацію, що може покращити кровопостачання і регенерацію тканин [5, 21].

Що стосується клінічних та інструментальних досліджень, то, на жаль, слід визнати, що при сучасному розвитку рівня знань неможливо задокументувати подібні зміни. Доплерівські дослідження не дали адекватних даних, які б чітко і однозначно вирішили це питання.

Залишаються також без відповіді такі питання: які можливі біологічні порогові дози сфокусованих і радіальних ударних хвиль; чи можливе передозування і чи виникають біохімічні зміни в тканинах; які зміни повинні відбутися на клітинному рівні, щоб виникли певні процеси [4].

Аналіз спеціальної літератури та клінічний досвід дають право висловити думку про те, що не можна допускати руйнування системи робочих тканин і органів, таких як нервові закінчення або кровоносні судини, тільки для того, щоб викликати біологічний ефрект, продукований ударною хвилею.

Завдяки емпіричному вивченню клінічних результатів уже стали відомі фрізичні параметри ЕУXT, але, на жаль, біологічні зміни у тканинах, викликані ЕУХT, на сьогодні ще недостатньо досліджені [4].

Існує припущення, що біологічна i, мабуть, молекулярна дії екстракорпоральних ударних хвиль $\epsilon$ не чим іншим, як механічним напруженням, здатним вивільнити окремі речовини біологічного організму, наприклад, вільні радикали, котрі тісно пов'язані з окисно-відновними процесами. Вільні радикали відіграють певну роль у клітинному захисті від різних стресових впливів. Вони мають як мінімум один неспарений електрон і можуть виявляти чітку хімічну активність. Найбільш важливими 3 них $\in \mathrm{O}_{2}$ (супероксиданіон), $\mathrm{OH}$ (радикал гідроксилу) i $\mathrm{NO}$ (радикал закису азоту).

Зміни окисно-відновного стану клітини частками кисню і водню дають підставу свідчити про вирішальну роль медіаторних молекул. Будьякий неконтрольований розвиток подібних реакцій може не тільки пошкодити клітину, а й викликати ії̈ загибель.

Стає зрозумілою важливість виявлення таких вільних радикалів у відповідь на механічне напруження, викликане ударними хвилями. Проведено дослідження, в якому у відповідь на механічне напруження, викликане екстракорпоральними хвилями, було показано утворення вільних радикалів. Серед виявлених речовин був і закис азоту.

Найбільш важливими властивостями радикалів $€:$ активація циклооксигенази гуанілу з наступною дилятацією судин; нейрозахист із наступним активуванням нейропередачі амінокислот, наприклад, глутамату; захист, виявлений у фрагоцитозі від чужорідних тіл і пов'язаний із вивільненням великої кількості NO та одночасною наявністю кисню.

Цей процес дозволяє використовувати реакцію з озоном, у результаті якої можуть бути виявлені газоподібні речовини. Синтез NO відбувається у шкірі в результаті зовнішніх впливів. У ході експерименту було перевірено два апарати ЕУХТ і встановлено, що вони швидко втрачають свою ефективність.

У подальших дослідженнях було виявлено інший доповнюючий механізм для нейтралізації часток кисню і водню, які складаються 3 «білків стресу», котрі виявляються через білки теплового шоку, які швидко й у великій кількості утворюються у відповідь на фрізичний та хімічний стрес.

Енергія ударних хвиль оцінюється як головний параметр. Вважається, що ударна хвиля може бути ефективною, якщо тиск досягає 5 мПа. Окремі захворювання потребують високої щільності потоку, але при цьому слід пам'ятати: низька щільність не потребує анестезії, може м'яко регулюватися i при необхідності збільшувати щільність. Значні коливання ударної хвилі можуть чинити негативний вплив на процес лікування, і тому лікар повинен знати, яку дозу енергії він застосував.

Стимулююча дія ударних хвиль виразно проявляється для сполучної, сухожилкової, 
епітеліальної, м'язової, нервової, а також кісткової тканин [2, 6, 8, 10, 14, 16, 17, 21].

Активація імунної системи характеризується підвищенням інтенсивності тиску і підсиленням функціональної активності імунокомпетентних клітин, зокрема лімфоцитів, лейкоцитів, а також зростанням утворення імуноглобулінів [2].

Однією 3 найістотніших особливостей дії ударної хвилі $\epsilon$ стимуляція мікроциркуляції, тобто кровообігу, що позначається на стані трофрічних процесів у тканинах. За сучасними уявленнями, під поняттям «мікроциркуляція» розуміють не тільки рух рідини судинним руслом, а й поза ним [11].

Мікроциркуляція забезпечує обмін речовин у тканинній мікросистемі, до якої входять клітини, специфрічні для даної тканини, сполучнотканинні утворення і фрізіологічно активні речовини [3]. Вона відбувається безпосередньо в мікроциркуляторному руслі, яке можна розглядати як систему, що складається з трьох ланок: кровоносної, лімфатичної і міжклітинної [19].

Унаслідок покращення мікроциркуляції визначаються чітко виражений протинабряковий ефект, зменшення напруження тканин, що викликає регенераторну, імуномоделюючу, протизапальну, десенсибілізуючу дії [7].

Важливим кроком у вирішенні теоретичних питань і практичних рекомендацій для ортопедії і спортивної медицини слід вважати роботи [14], в яких наведено результати досліджень впливу ударних хвиль високої енергії в лікуванні несправжніх суглобів. Дослідження довели, що ці хвилі викликають мікрокровиливи, які сприяють формуванню кісткової мозолі, що стимулює зрощення переломів з уповільненою регенерацією, а головне, без оперативного втручання приводить до ліквідації псевдоартрозів.

Дані клінічних спостережень та експериментальних досліджень свідчать про те, що існують зони нейроміоостеофіброзу у ділянках шийного, верхньогрудного та поперекового відділів хребта, біля кісткових структур верхніх та нижніх кінцівок, а також локальних ділянок гіпертонусу в пара- та екстравертебральних м'язах, що характеризуються болісністю і локальним ущільненням.

В основному найбільший ефект у лікуванні ударними хвилями мають ті зони нейроостеофіброзу, пальпація яких викликає іррадіацію больових відчуттів. У комплексі лікувальних методів, що безпосередньо діють на вогнище ураження, значне місце посідає вплив через точки акупунктури.

Акупунктурні ефекти базуються на взаємодії соматичної і вісцеральної аферентації у нервових структурах. Акупунктурна терапія передбачає крім цілеспрямованої дії адекватний спосіб стимуляції зони впливу, при цьому ключовою $є$ акупунктурна зона [22].

Ударні хвилі за рахунок високої концентрації нервових та судинних компонентів активно впливають на внутрішнє середовище організму і корегують сукупність електромагнітних явищ у живій системі.

В одній із наукових праць ішлося про те, що захворювання осіб, які займаються тяжкою працею, викликаються позамежними фрізичними навантаженнями або мікротравмами. При цьому в патологічному процесі, який у США відомий як «тригерпункти», порушується рівновага нервовом'язової системи, а в місцях зіткнення нервових закінчень із м'язовими волокнами утворюється довготривалий спазм останніх, що викликає болісне скорочення частини або усього м'яза. Також зазначалося, що традиційне лікування (знеболювальні засоби, масаж, голкотерапія, фрізіотерапія), на жаль, малоефективне і потребує багато часу. Ударно-хвильова терапія, за даними W. Bauermeister, легко долає м'язовий спазм i характеризуєтся коротким терміном одужання.

У 2006 p. H. Everke почав застосовувати радіальні хвилі замість голок для акупунктури і визначив, що цей метод порівняно з класичною голкотерапією краще сприймається пацієнтами, навіть дітьми.

Перевага методу лікування ударними хвилями полягає в консервативному втручанні, яке не викликає болю, триває не більше 10 хв і складається максимум із п'яти сеансів.

Останні гістологічні, біохімічні та імунологічні дослідження суттєво покращили наше уявлення про вплив ударних хвиль на тканини, оброблені ЕУXT [11].

До них належать підвищена васкуляризація, прискорене виділення фактора росту, вибіркове невральне інгібіювання, рекрутування стовбурових клітин та інгібіювання молекул, що відіграють певну роль у запальному процесі. Невральне інгібіювання, підвищені неоваскуляризація і виділення гормону росту, мабуть, справляють найбільш важливий вплив на сухожилок та м'язову тканину. ЕУXT чинить як центральний, так і периферійний вплив на нервову активність. Так, Майєр 3 колегами продемонстрували, що цей метод привів до суттєвого зниження речовини $\mathrm{P}$ у кроля через 6 тиж. після лікування [11]. Що стосується перифрерійного впливу, то ЕУХТ володіє вибірковою фрункцією сенсорних немієлінізованих нервових волокон, не впливаючи на більш крупні рухливі нейрони [12]. 
Застосування ударних хвиль веде до вивільнення нейропептидів, таких як кальціотонін ген зв'язаний пептид (CGRP), що веде до локального, «нейрогенного запалення» і запобігає реінервації сенсорних нервів в обробленій ділянці.

Висловлюється припущення, що саме це інгібіювання реінервації сприяє довгостроковому зниженню больових відчуттів. Ударні хвилі, за даними окремих авторів, регулюють експресію білків і фракторів росту шляхом їх підвищення, що позитивно впливає на ангіогенез.

Вплив ЕУХT низької енергії на сухожилковокісткові з'єднання привів до збільшення числа нових судин і появи ангіогенезу зв'язаних маркерів, включаючи ендотеліальний синтез оксиду азоту, ендотеліальний фактор росту судин (VEGF) і ядерний антиген, які проліферують клітини порівняно з контрольним з'єднанням. Слід зазначити, що VEGF - важливий мітогенний фактор васкулярних ендотеліальних клітин, а проліферація ендотеліальних клітин - це критичний аспект ангіогенезу.

У результаті отриманих даних експериментальних досліджень було зроблено таке припущення: після впливу ударної хвилі на клітинну мембрану остання та білок на ній виявляються більш чутливими до нормального напруження i напруження зміщення, після чого сигнал з білка мембрани передається у клітину.

У ході різних експериментальних досліджень спостерігали вплив радіальних ударних хвиль на ендотеліальні клітини in vitro. На цій підставі зроблено висновок, що після їх впливу окремі хвилі дезінтегруються, тоді як інші володіють високою здатністю збільшувати інтенсивність росту клітин in vitro, що підтверджується підсиленням генної експресії.

Деякі зарубіжні учені продемонстрували, що ЕУХТ низької енергії сприяє заживленню викликаної колагеназою ентезопатії п'яткового сухожилка щурів, викликаючи трансформування фактора росту бета I (TGF-bl) і інсуліноподібного фрактора росту I (IGF-I), та довели, що вони можуть чинити анаболічний вплив після ушкодження тканин.

J. P. Furia i J. D. Rompe у роботі «Extracorporeal Shock Wave Therapy» відмітили, що ЕУХT, мабуть, справляє свій вплив на сухожилкову тканину шляхом регулювання білків, котрі мають певне значення для ангіогенезу, вибіркового інгібіювання аферентних нервових волокон, а також стимулювання виділення фактора росту, що має велике значення в процесі заживлення сухожилків.

ЕУХТ застосовують для покращення відновлення тканин i їх регенерації - процесів, в які втягнуто стовбурові клітини і клітини-попередники. Виникає запитання: чи може впливати ударна хвиля на стовбурові клітини, що беруть участь у регенерації тканин?

Відомо, що залежна регенерація мезенхімальних стовбурових клітин (МСК), одержаних з кісткового мозку дорослої людини, може покращитися в результаті збільшення міграції, проліфрерації і зниження апоптозу.

У зв'язку з тим що два різних види ударних хвиль, а саме фокусовані і радіальні, покращують процеси залежної регенерації стовбурових клітин, виникла необхідність вивчити їх вплив на мезенхімальні стовбурові клітини.

W. Bloch, V. Delhasse, H. Neoland et al. використовували експериментальний зразок культури клітин для ЕУХТ в абсорбуючих умовах. Вплив фокусованих і радіальних ударних хвиль на МСК вивчали з точки зору життєдіяльності клітин (міграції, проліферації і апоптозу) в умовах різних імпульсів, частоти та інтенсивності енергії. Дані дослідження засвідчили, що обидва методи можуть впливати на біологічну поведінку клітин залежно від інтенсивності імпульсу, частоти й інтенсивності енергії.

Специфічна різниця відмічається між ними 3 точки зору оптимального діапазону дозування на проліферацію [23]. Обидва види ударних хвиль впливають на міграцію й апоптоз МСК, а при більш високих інтенсивностях позитивний вплив на проліферацію, апоптоз і міграцію є оберненим.

В останні роки вплив ударної хвилі на живі тканини досить широко використовується в медицині і хімічній інженерії. Це екстракорпоральна ударно-хвильова літотрипсія, системна доставка лікарських речовин до зони дії, біопроцеси захисту навколишнього середовища і тканинна інженерія.

У лікуванні, спрямованому на регенерацію кісткової тканини за допомогою екстракорпоральних ударних хвиль, відмічено позитивні результати. В дослідженні Tamagawa М. було визначено, що не всі клітини дезінтегруються міцною ударною хвилею $(0,5 \mathrm{MPa})$ і короткою тривалістю (50 мс) [24].

Таким чином, можна припустити, що м'які клітини, такі як ендотеліальні, мають потенціал регенерації або швидкого росту під впливом високого тиску і короткого терміну від 1 до 100 мікрос.

За результатами дослідження було встановлено, що ударна хвиля має здатність стимулювати регенерацію клітин кісткової тканини. Стосовно впливу фокусованих ударних хвиль на живі клітини і тканину, слід зазначити, що 
поле фокусованого тиску в екстракорпоральному ударно-хвильовому приладі важко визначити, щоб оцінити рівень робочого тиску. Крім того, в фрокусованій зоні повинні визначатися пухирі кавітації.

Проводилися дослідження впливу дії ударних хвиль на ендотеліальні клітини in vitro, що дало авторам підставу висловити думку про те, що після впливу ударної хвилі на клітинну мембрану остання або білок на ній виявляються більш чутливими до градієнта, тобто нормального напруження i

\section{Література}

1. Bjurholm A. Substance P- and CGRP-immunore active nervus in bone / A. Bjurholm, S. Kreicberg, E. Brodin et al. // Peptides. - 1988. - 9. - P. 165-171.

2. Dahmen G. P. Skrodies: Extracorporale Stosswellentherapie (ESWT) in knochennahen Weichteilbereich an der Schulter / G. P. Dahmen, L. Meiss, V. C. Nam // Extracta Orthoped. - 1992. - 11. - P. 25-27.

3. Delius M. Biological effects of shock waves: in vivo effect of high energy pulses on rabbit bone / M. Delius, K. Draenert, Al. Diek et al. // Ultrasound Med. and Biol. 1995. - 21. - P. 1216-1225.

4. Gremion G. rESMT bci dez Tendinosis Calcarea / G. Gremion et al. // Extracorporale Stosswellentherapie / ed. L. Gerdesmeyer. - Nordersteat: Books on Demand $\mathrm{GmbH}, 2004$. - P. 198-211.

5. Haake M. Absence of spinal response to extracorporeal shock wave on the endogenous opioid Systems in the rat / M. Haake, A. Thon, M. Bette // Ultrasound Med. and Biology. - 2001. - 27. - P. 279-284.

6. Halst J. Die osteorestavration via Stosswellenanwendung. Eine neue Möglichkeit zur Therapie der gesförten knochernen konsolidierung // Ñ. Chaussy, C. F. Eienberger, D. Wilbert (Hreg.) / J. Halst // Die Stosswelle Forschung und Klinik. Tübingen: Attempto Verlag, 1995. - P. 157-161.

7. Haupt G. rESWT-Terapie beim Fersensporn (Fascitis plantaris) / G. Haupt, R. Diesch, T. Shaub et al. // Extrakorporale Stosswellentherapie / ed.: L. Gerdesmeyer. - Norderstedt: Books on Demand GmbH, 2004. - P. 167-182.

8. Hünsler E. Anregung von Stosswellen in Flussingkeuten durch Hochgeschwindigkeets wass ertrop ten / E. Hünsler, W. Kiefer // Verband Detsch. Physikal. Gesellsoh aft. 1971. - 6. - P. 786.

9. Levine I. D. Intraneuronal substance $\mathrm{P}$ contributes to the severity of treated arthritis / I. D. Levine, R. Clark, M. Devon et al. // Science. - 1984. - 226. - P. 547-49.

10. Maier M. Basic research of applying extracorporeal shockwaves on the musculosceletal system. An assessment of current status / M. Maier et al. / / Orthopädi. - 2002. - 31 (7). - P. 667-77.

11. Maier M. Molekulare Wirkmechanismen von stoss wellen / M. Maier, G. Schmitz, I. Hausdorf // Extracorporale stoss wellen therapie: ed. L. Gebersmeyer. - Norderstedt: Books on Demand Gmbn, 2004. - P. 42-56.

12. Ohtori S. Shock wave application to ratsin induced degeneration and reinervation of sensory nerve fibres / S. Ohtori et al. // Neuroscience. Letters. - 2001. -315. - P. 57-60.

13. Rompe I. D. Evaluating the rick of scitic nerve damage in the rabbit by administration of low intermediate energy напруження зміщення, ніж у випадку квазістатичного тиску, після чого сигнал з білка мембрани передається у клітину. Автори зробили висновок, що ріст клітин під дією радіальних ударних хвиль підтверджується підсиленою експресією.

Таким чином, дослідження засвідчили, що ударні хвилі можуть чинити позитивний вплив на відновлення і регенерацію тканин шляхом активації стовбурових клітин, разом із тим при більших інтенсивностях ударних хвиль їхній ефект може виявитися протилежним.

extracorporeal shock waves / I. D. Rompe, I. Bohl, H. Riehle et al. // Z. Orthop. Ihre Grenzgeb. - 1998. - 136. P. $407-411$.

14. Schleberger $R$. Non-invasive treatment of long-bone pseudarthrosis by shock waves (ESWL) / R. Schleberger, T. Senge // Ach. Orthop. Trauma Surg. - 1992. - 111. P. 224-227.

15. Schmitz Ch. New aspects: molecular Working Mechanisms /Ch. Schmitz, M. Maier// First Atrad Congress on Shockwave Treatment for Musculoskeletal Pain. - 2008. Abstracts. - 9 .

16. Schöll I. Sportinduzierte Kremkhunsbilder Behandlung von Achillodenyie, Patell aspiten syndrom und Tibikantensyndrom mitradialen stosswellen (rESWT) / I. Schöll, H. Lohrer, S. Arentr // Extracorporale Stosswellentherapy; ed. L. Gerdersmeyer. - Norderstedt: Books on Demand $\mathrm{GmbH}, 2004$. - P. 102-143.

17. Schöll I. Extracorporal shockwave therapy in case of injuries and diseases of the locomotor system in athletes / I. Schöll, H. Lohrer, S. Arentr // Sports Medicine. - 2010. 1-2. - P. 37.

18. Shin C. Neurogenic Substance $P$ stimulates osteogenesis in vitro / C. Shin, C. W. Bernard // Peptides. 1997. - 18. - P. 3223-32.

19. Tsai W. C. Treatment of proximal plan for fasciitis with ultrasound-guided steroid injection / W. C. Tsai, C. L. Wang et al. // Arch. of Physical Med. and Rehabilitation. - 2000. - 81. - P. 1416-21.

20. Ueberle F. Shock Wave Technology / / Extracorporal Shock Wave in Orthopedics / F. Ueberle, W. Siebert, M. Buch (Hrsg) // Berlin: Springer. - 1997. - P. 59-87.

21. Wang $C$. J. Shock wave therapy includes neovascularization an the tendonbone junction. A study in rabbits / C. J. Wang, F. S. Wang, K. D. Yang // J. Orthop. Res. 2003. - 21. - P. 984-989.

22. Bauermeister $W$. Myo fasziales triggerpunkt - Syndrom: Diagnose und Therapie dur'h Stoßwellen / W. Bauermeister // Extr. Orthopedica. - 2007. - P. 12-19.

23. Bloch W. Experimental studies: focused and radial shock, wave treatment, influence human mesenchimal stem cells / W. Bloch, V. Delhasse, H. Nevlandetal // First altrad congress in Schock wave treatment for musculoskeletal pain. - Berlin, 2008. - Abstact. P. 12.

24. Tamagawa M. Aculeration of cell growth rate by plane shock wave using shock tube / M. Tamagawa, N. Ichimatsuetal // Shock Waves $2 G^{\text {th }}$ International Symposium on Shock Waves. - K/ Hannemann: F. Seiler (Eds.) - Springes, 2009. - Vol. 2. - P. 11-13. 